\title{
CULTURAL-ECOLOGICAL THEORY AND THE LANGUAGE EDUCATION OF ROMA CHILDREN
}

\author{
Hristo Kyuchukov \\ Magdeburg-Stendal University of Applied Sciences \\ Breitscheid str., 2, Magdeburg Germany, 39114
}

\begin{abstract}
The paper presents results from language testing of 70 Roma children from Bulgaria pupils of grade 1, studying in one of the biggest Roma settlement's schools in Sofia, "Fakulteta" district. The children were tested using the Peabody Picture Vocabulary Test. The test measures language comprehension and language production of the children at the beginning and end of the school year. Between the first and second testing, the teaching methodology in instruction for the children was changed - a Roma assistant teacher whose task was to use the mother tongue of the children as a communicative tool was introduced to the classes. The results of the children during the second testing were substantially better and they are discussed in the light of the theory of the American anthropologist J. Ogbu, who developed his cultural-ecological theory (CE) in the 1980s. The results of the children are analyzed via dispersion analysis using ANOVA. According to Ogbu's CE theory, the school success of minority children depends on the attitudes of the society at large and the level of community support. The paper also briefly discusses the reason why the de-segregation of the Roma children and their integration into mainstream schools in Bulgaria has largely proved to be a failure.
\end{abstract}

Key words: cultural-ecological theory, Roma, mother tongue, desegregation, Bulgaria

\section{Introduction}

After World War II, the Roma in all East European countries were resettled by force in ghetto-type settlements and their nomadic life was forbidden. The settlements were usually located outside of the towns and/or villages or at their periphery. In the 1960s and 1970s, the governments built schools and kindergartens for Roma children. The initiative behind these schools was very progressive at the beginning, however later the schools became a place of segregation of Roma children, where they received low-quality education compared to non-Roma children educated in mainstream schools. In the early 2000s, Roma organizations and Roma activists in Europe began a struggle against the existence of those schools and they were trying to integrate the Roma children in mainstream schools where they could study together with majority children. However, the results of these efforts were not positive. In the $21^{\text {st }}$ century, in most East European countries the segregated schools still exist: the children do not have access to high-quality education, no access to books and other facilities which can help to make the educational process successful. The educational staff in most cases lacks specific preparation to work in those types of schools, and the schools and kindergartens still exist, as well as the ghettoized types of settlements in East European countries. 
The life in the ghetto settlements is very intense. The community life is well organized. The Roma develop all kinds of internal "institutions". The children acquire knowledge in the Romani language as a mother tongue from a very early age, and due to the informal "community education" they learn about the value system of the community, exactly as it is in other ethnic communities (Akande, 2007). The children participate in all forms of community life and in the Roma community everyone is obliged to take care of the children, to play and joke with them, to teach them songs, dance with them or tell them fairytales. So by the age of 5 the Roma children, due to contacts with different adults with different registers, have a good knowledge of the Romani language and the structure and function of the community. It is known that the type of the family in general influences the children's academic success (Han, 2006; Kyuchukov, 2014). Han (2006) compares non-Hispanic white children, and children of Latin-American regions with lower reading and math scores, with children of Asian regions who have higher reading and math scores. In addition, the migrant children may have either higher (e.g., children from East Asia) or lower scores (e.g., children from Mexico) by first grade. According to Han, the child and family characteristics play a key role in the differences in children's academic achievements. Home, school, and neighborhood environments may also matter but to a lesser extent.

The Roma in Bulgaria arrived there as migrants some 8-9 centuries ago, coming originally from India. However, only in the last 60-70 years have successive Bulgarian governments attempted to integrate Roma, using different methods. Despite educational measures, the Roma are still marginalized and excluded, they face difficulties with integration into Bulgarian society. The main reason for such a situation is the education the Roma children receive in ghetto-type schools (Kyuchukov \& New, 2016).

The research question which this article seeks to answer:

What is the knowledge of first-grade Roma children concerning L1 and L2 vocabulary in ghetto-type schools in Bulgaria and how does their knowledge substantiate or non-confirm Ogbu's cultural- ecological (CE) theory?

\section{Ogbu's Cultural-Ecological Theory}

According to Ogbu (2014), the communities transmit the cognitive skills to their children through various techniques of socialization: "children are socialized to acquire the cognitive skills of pattern of intelligence that exist already in their culture, because their culture requires it; it is functional in the culture" (p. 366). Ogbu writes that the minorities who are doing well are those who stay close to their ancestral cultural practice in socialization. He systematized his observations in a theory which he calls "culturalecological theory," which explains the minority children's failure in the educational system. In a number of publications, Ogbu $(1978,1982,1990)$ describes the culturalecological theory. It is connected with minority students' performance. He writes that "two sets of factors influence minority school performance: how society at large and the school treats minority groups respond to those treatments and to schooling (community forces). The theory further points that differences in school performance between immigrant and non-immigrant minorities are partly due to differences in their community forces" (Ogbu, 1990, p. 156) 
His typology of autonomous, immigrant and caste-like minorities, his concepts of primary and secondary cultural differences, as well as his views regarding the importance of a group's cultural frame of reference and community forces for educational outcomes will be examined here regarding the Roma minority in Bulgaria.

The fact that there are minority groups which achieve less academically in various societies gave him the basis to distinguish different types of minority groups. Autonomous minorities have a specific ethnic linguistic, religious or cultural identity (for example the Jews, Amish and Mormons in the U.S.). They might be victims of prejudice, but they are not "subordinated" in the social, economic or political system. Immigrant minorities became part of a large society on a voluntary basis. They acculturate in an additive process (accommodation without assimilation) by overcoming language differences and differences between their cultural systems and that of the dominant host society. Over time the primary cultural differences and even experiences of discrimination do not prevent their efforts to integrate into mainstream society. Cast-like minorities (African Americans, Native Americans) were brought into U.S. society involuntarily, through slavery or colonization. "Suffering from prolonged discrimination by the dominant society, these groups have developed secondary cultural differences and an oppositional cultural frame of reference. Cultural and language differences between minority group members and the dominant society arose after groups became an involuntary minority. For many group members, these differences are regarded as markers of identity to be maintained. Certain forms of behavior, symbols and meanings that are characteristics of the dominant group are seen as being inappropriate or undesirable. "This tendency, which Ogbu calls "cultural inversion", compels minority members to choose between conforming to their own group's model of behavior or the model of the dominant group. While autonomous minorities and voluntary minorities (after a period of a transition in which they have to overcome language and cultural barriers) for the most part achieve similar or even better academic results compared with the majority, involuntary minorities, in general, have little academic success" (Luciak, 2004, p. 360).

Foster (2004), analyzing Ogbu's CE theory as a theory of minority student performance, says that Ogbu also worked toward a global and cross-cultural theory of minority education. According to Foster (2014, p. 371), "Ogbu felt that the impact of community forces upon minority responses to schooling was consistently understudied. [...] Given Ogbu's idea that the community and system forces are both important for understanding minority responses to schooling, it is important to note that, even as he focused on maladapted cultural norms and values of involuntary minorities, he did not assume that there was no discrimination against minorities. Nor did he assume that discrimination did not have direct negative effect upon minority academic outcomes". According to Ogbu (1985), the cultural and language differences between minority and majority groups lead to learning difficulties. Speaking about language, he takes into account even the dialect differences as cultural difference among the minority groups.

In Russian psychology, Vygotsky's work (1978) shows how children learn through active communication with adults. Human beings interact with their worlds through cultural artifacts, tools, and symbols, including language. Language from a culturalhistorical perspective is considered the leading tool for learning and human development and is said to mediate individuals' activity in the valued practices of their communities across a lifespan (Cole, 1996). 
The works of Vygotsky, Cole and Ogbu have largely the same basis: the authors show the importance of the communication with adults in the process of cognitive and language development. All of them use the culturally specific symbols as a tool for development and learning. Ogbu's work is specifically focused on minority/migrant and refugee children who are somehow excluded from the society. Ogbu shows the importance of the community support for the children's school success.

Romani culture is not a homogeneous culture: there are many groups with different status in Roma society around the world. The Romani language is not a standardized/ codified language. It comprises numerous different dialects. The dialects have differential status among Roma groups. However, Roma are discriminated against in many societies without it being taken into account to which group of Roma and what socioeconomic class they belong, and what dialect they speak. For many in the majority society, the Roma are essentialized as being "lazy, dirty and criminals". Within the vortex of such prejudices, they do not care about real individuals and all Roma groups face all manner of discrimination in the society, various institutions, and most particularly as children and teens in the educational systems available to them.

Although Roma have different status in different European countries, the Roma children face discrimination, widely placed segregated or channeled into so-called "special schools" (schools for mentally retarded children), and in most countries they show very low school achievement results. This is illuminated in a number of publications by Kyuchukov, (2011) on Bulgarian Roma children, by Kwadrans (2010) on Polish Roma children, by Balvin \& Vavrekova (2013) and Samko \& Kapalkova (2014) on Slovak Roma children and by Kaleja \& Zazulkova (2012) examining the situation of Czech Roma children. There is only one publication applying Ogbu's CE theory to Roma education (Bruggemann 2014), seeking to 'test' and non-substantiate certain aspects of Ogbu's theory. The author interviewed 10 Spanish Roma (Gitano) university students. Due to historical development of the Roma, the Spanish Gitano are not the typical case of school success or its absence. Most of the Gitano in Spain no longer speak the language of Gitano (Cal - Spanish Romani dialect). They only speak Spanish. In school they do not have any language or dialect differences from majority children and this makes their education much easier and more successful. The Roma students are well integrated in the school. Although Bruggemann says that the students do not abandon their culture and identity, actually they do not face such a degree of segregation or marginalization as the Roma children from other European countries like Bulgaria or Slovakia. Interviews with 10 students cannot bring enough strong evidence to substantiate or disprove a theory or to criticize any ideas and make generalizations. The application of Ogbu's CE theory to the case of Spanish Roma is non-conclusive and hardly useful in analyzing the actual problems of Roma minority children at school or their later success in society in much of Eastern Europe.

\section{Study}

The aim of the study described here was to examine the vocabulary richness of Roma children in first grade in a Bulgarian segregated school, based in the largest urban Roma ghetto in Bulgaria, "Fakulteta" in the capital Sofia. 70 children from the first grade, between the ages of 6-7, were tested utilizing the Peabody Picture Vocabulary Test, 
measuring vocabulary richness in their mother tongue Romani and in their second language, Bulgarian. The knowledge of the children pertaining to singular and plural nouns and the verbs was measured. The children were tested twice - at the beginning and end of the 2013-2014 school year. The statistical analyses were done with ANOVA.

Working together with the teacher in the class was also a Roma assistant teacher. The goal of the Roma assistant teacher is to do additional work with the children in afterschool extra-curricular activities using both Romani and Bulgarian as languages of instruction. The language of instruction is Bulgarian, and at home and between themselves the children speak Romani.

The school is based in the Fakulteta ghetto and $100 \%$ of the children are of Roma origin. The total number of the students in grades $1-12$ at the time of the study was 1,200. In the mainstream Bulgarian schools, there are no Roma assistant teachers. Even if there are Roma children in the mainstream classes, the Roma assistant teacher does not exist to supplement instruction.

\section{The results}

The nouns in singular. During the first testing at the beginning of the school year, the children displayed a low level of knowledge of the nouns in both languages (only $37 \%$ of the lexemes). During the second testing, done at the end of the school year, the results were much better ( $45 \%$ of the words tested). The differences between the first and the second testing are statistically significant: $F(1.68)=22.26, p<.0000$, as is shown in figure 1 .

LEVELS Main Effect

$F(1.68)=22.26 ; p<.0000$

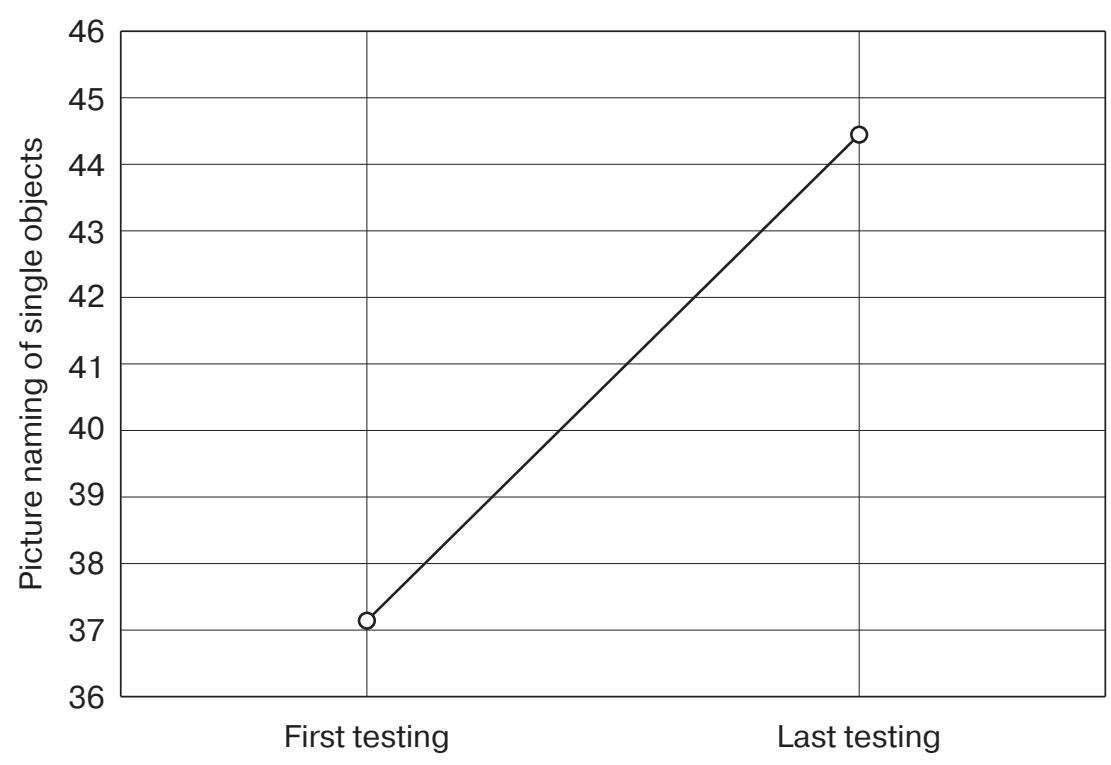

LEVELS

Fig. 1. Level of knowledge of nouns in singular 
Performing a factoral analysis, we observed the influence of the factors "language" and "testing" on the results of the children. As is shown in figure 2, during the first testing the children had better results in Romani than in Bulgarian. During the second testing, the results in Bulgarian were better than those in Romani. The better results in knowledge of Bulgarian nouns (35\% at the beginning vs. $46 \%$ at the end of the study) are due to the additional work of the Roma assistant teachers during the after-school activities. However, there was no such notable increase in the results in their mother tongue, i.e. Romani nouns. In fact, that literacy in Romani does not exist. They don't learn to read and write in Romani, and they do not learn much about the Romani grammar, they have no exposure books in Romani at home or in the community. The differences in the knowledge of the nouns between Romani and Bulgarian at the beginning of the study is statistically significant, $F(1.68)=6.27, p<.0147$, but the differences are not statistically significant during the second testing. The knowledge of the children regarding singular nouns in Romani and in Bulgarian during the second testing is almost the same (43\% in Romani vs. $46 \%$ in Bulgarian).

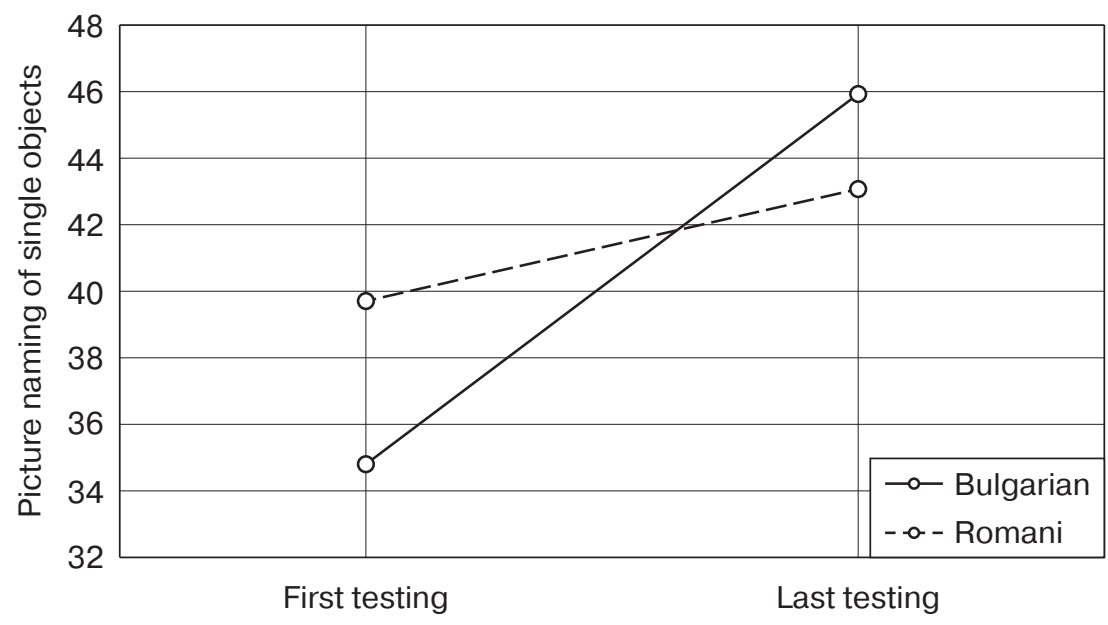

LEVELS

Fig. 2. The influence of the factors "language" and "testing" on the level of knowledge of the noun - singular

The nouns in plural. Figure 3 shows the results from the testing of the nouns in plural. Similarly to the previous results in singular, the children show lower results during the first testing. During the second testing, the results are much higher and the differences are statistically significant $F(1.68)=21.53, p<.0000$ between the first and second testing.

The factors "language" and "testing" have a significant influence on the results of the children, testing their knowledge regarding the nouns in plural. Again during the first testing, the children show better results in Romani naming the plural nouns. The differences between the knowledge of Romani and Bulgarian nouns in plural during the first testing are statistically significant: $F(1.68)=4.09$ и $p<.047$. During the second testing, the children have better results in both languages and there is no statistical 
differences between the Romani (L1) and Bulgarian (L2) knowledge of plural nouns. These developments are shown in figure 4.

LEVELS Main Effect

$F(1.68)=21.53 ; p<.0000$

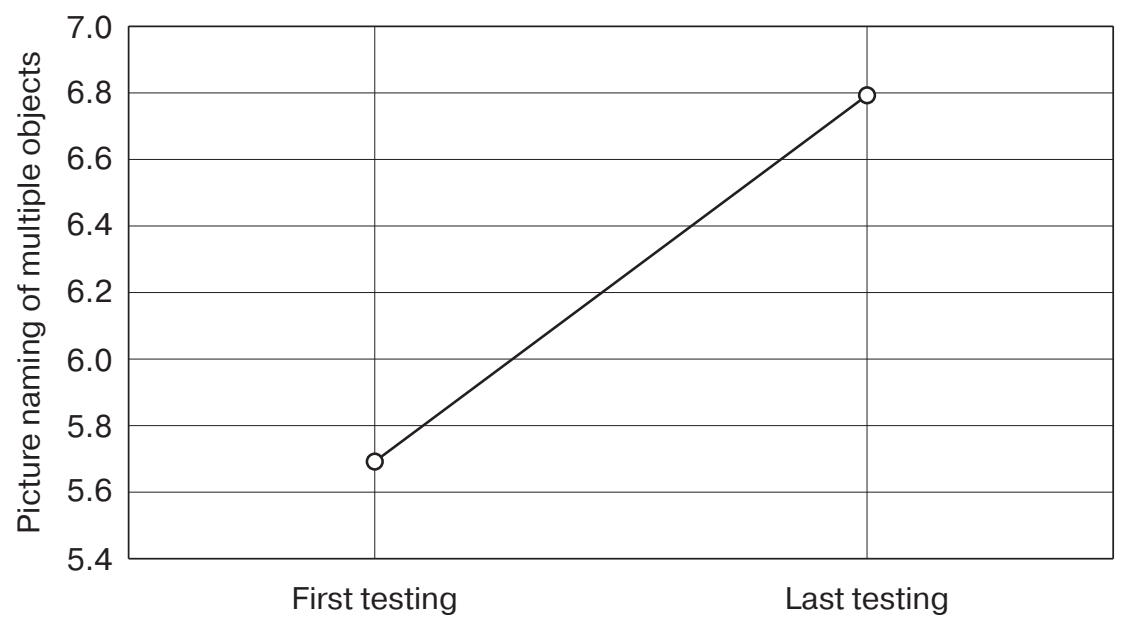

LEVELS

Fig. 3. Level of knowledge of nouns in plural

2-way interaction

$F(1.68)=4.09 ; p<.0471$

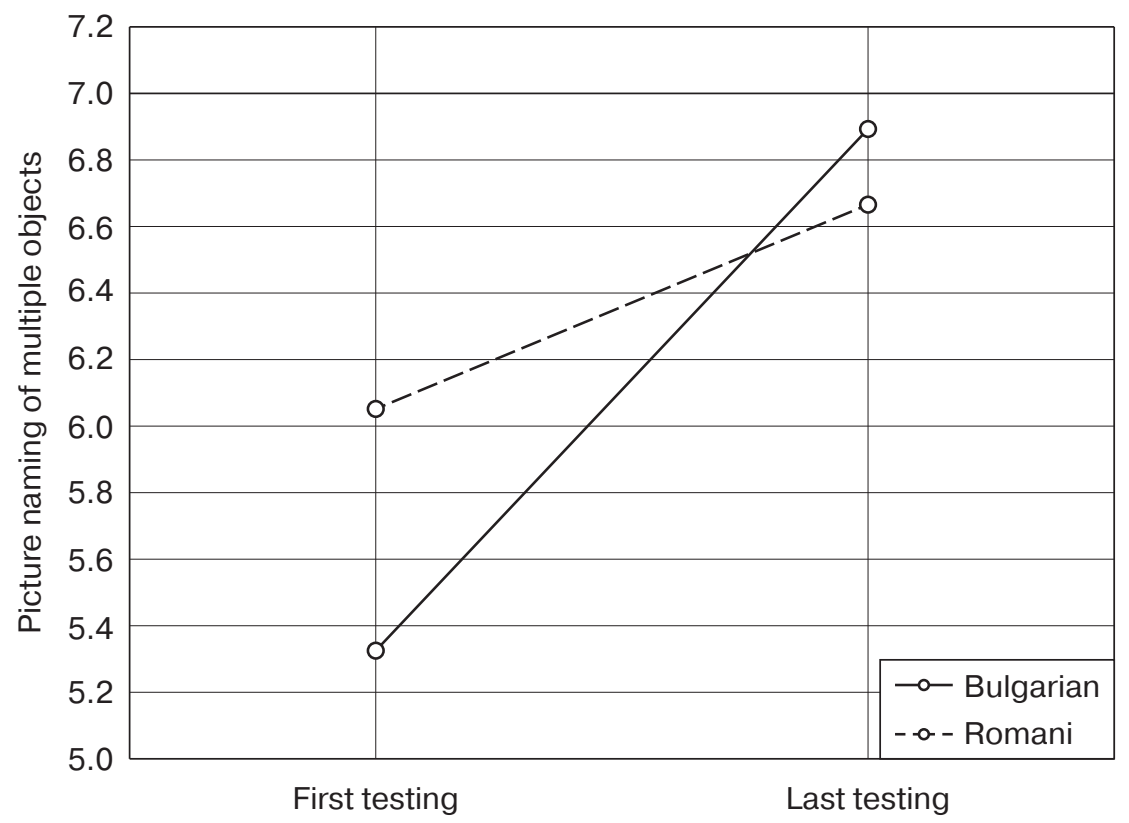

LEVELS

Fig. 4. The influence of the factors "language" and "testing" on the level of knowledge of the noun — plural 
The verbs. In psycholinguistics it is commonly recognized that the verbs are the next grammatical categories which are acquired in language development. During the first testing, the children show better results in Romani verbal system. The knowledge of Bulgarian verbs is weaker. The differences are significant $(F(1.68)=4.63, p<.0349)$. During the second testing, the results in Bulgarian are better than the results in Romani. It is interesting to see that children's knowledge of the Romani verb system does not increase. That shows most probably that the children by the age of $6-7$ already know most of the common everyday verbs in their mother tongue. These findings are shown in figure 5 .

2-way interaction

$F(1.68)=4.63 ; p<.0349$

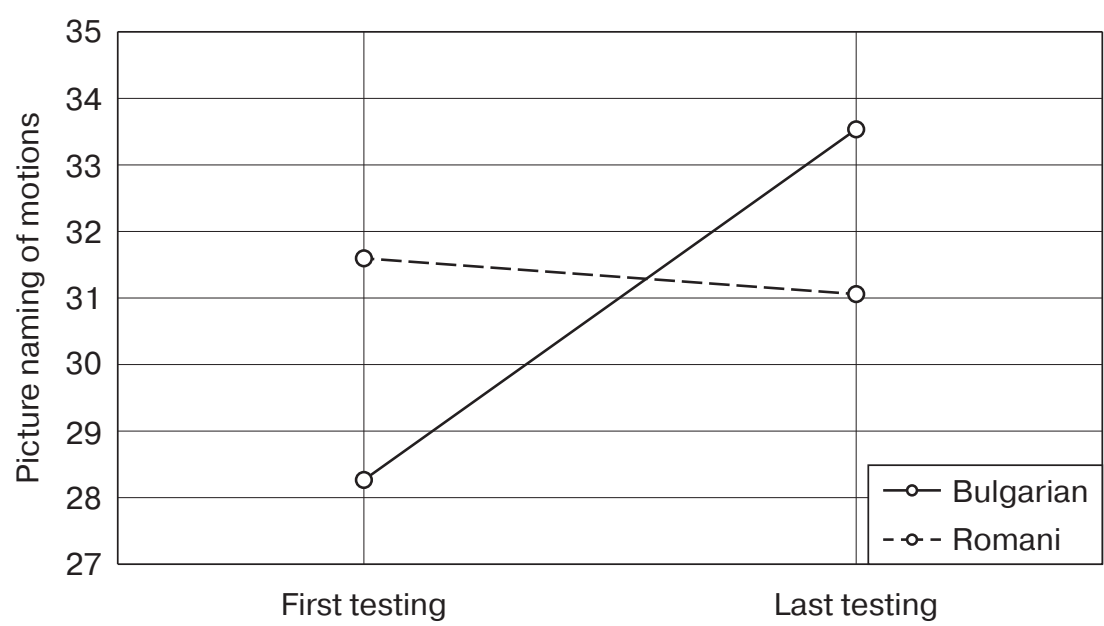

LEVELS

Fig. 5. The influence of the factors "language" and "testing" on the level of knowledge of verbs

\section{Discussion and conclusions}

The results from the study show that the children have progress in learning the nouns in singular and plural in both L1 and L2 between the two testing. They have increased their knowledge of verbs between the first and second testing in their L2 Bulgarian, but their knowledge of the verbal system in their mother tongue - Romani - did not change. The differences of the results between the first and second testing and between the languages: Romani (L1) and Bulgarian (L2) are statistically significant. It seems that the presence of a Roma assistant teacher has a positive influence on the results of the children in the official language, and to some extend helped the children to develop their knowledge in their mother tongue.

Associating the results of the Roma children from the testing Ogbu's cultural-ecological theory, and cultural-historical model of Vygotsky, where the communication and support from family, community and society play an important role in the school success of the children, it is clear that the majority society does not care about the segregated schools and performance levels there. However, the community and the parents are those who 
really care and wish their children to have a good education. The local NGOs based in the ghetto settlement, through projects and community organization, endeavor to increase the quality of the educational process in the local school.

The initiative of Roma NGOs to bus the Roma children to mainstream schools populated predominantly with majority children did not yield the expected results, because the society at large retains very negative attitudes and discriminatory behavior toward Roma children in mixed schools. This serves to substantiate Ogbu's CE that postulates that the presence of an aggressive and discriminatory school environment, even if the minority family are supportive to their children, will negatively influence the academic success of minority children. In the availability of a friendly and supportive school environment, where the Roma assistant teachers were present, the children showed much better results.

In one of my visits to India, I visited the Muslim neighborhood in the city of Hyderabad. Approximately 1 million Urdu-speaking minority Muslims live in that district. I visited two schools located approximately $200 \mathrm{~m}$. from each other on the same street. The children in both schools were with the same ethnic and socio-economic status, the teachers were from the same community, with the same language, culture and religion. The first school was a state school and the second was a private school. The children from the state school showed low results in the state exams and the children from the private school always achieved better results on the state exams. The two schools were absolutely the same by interior design and access to facilities. The only differences between the two schools were are the methods used by teachers in teaching the children. The state school used more traditional teaching methods where the children do not enjoy much freedom. The private school used more interactive and innovative methods of teaching and importantly, they had assistant teachers in the class, and the children enjoyed much more freedom during the educational process.

The method which we used in the ghetto-type school in Sofia, Bulgaria with Roma children was non-traditional, innovative and interactive, using the children's language and culture as a motivating factor for learning. The presence of supportive additional staff - importantly, from the same culture and religious background - in the classroom also helped the children to see the school as a friendly and supportive space for studying and learning. The study also shows that there is a need for a training program at university level for 'assistant teachers' in Bulgaria. Some years ago such a program existed at the University of Veliko Tarnovo, in Bulgaria, but because of political reasons the program was closed down. This is, we would argue, a structural guarantee for the educational success of Roma children. Additional research on such factors is necessary.

\section{REFERENCES}

Akande, J.O. (2007). The practice of community education in Nigeria. Educational Research and Review, 2 (10), 264-270.

Balvin, J. \& Vavrekova, L. (2013) Education of Roma students - always current but controversial topic. In: J. Balvin, L. Kwadrans, H. Kyuchukov (Eds). Roma in Visegrad Countries: History, Culture, Social Integration, Social Work and Education (pp. 325-332). Wroclaw: PROM.

Brüggemann, C. (2014). Romani culture and academic success: arguments against the belief in a contradiction. Intercultural Education, 25(6), 439-452. doi: 10.1080/14675986.2014.990229 
Cole, M. (1996). Interacting minds in a life-span perspective: a cultural-historical approach to culture and cognitive development. In P.B. Baltes \& U.M. Staudinger (Eds.). Interactive Minds: Life-span Perspectives on the Social Foundation of Cognition (pp. 59-87). Cambridge University Press: New York.

Foster, K.M. (2004). Coming to terms: a discussion of John Ogbu's cultural ecological theory of minority academic achievement. Intercultural Education, 15(4), 369-384. doi: 10.1080/1467598042000313403.

Han, W.-J. (2006). Academic achievements of children in immigrant families. Educational Research and Review, 1 (8), 286-318.

Kaleja, M. \& Zazulkova, E. (2012). The Context of Special Educational Needs of Selected Pupils in Primary Education. Ostrava: The University of Ostrava.

Kyuchukov, H. \& New, W. (2016) Diversity vs. equality: Why the education of Roma children does not work. Intercultural Education, 27 (6), 629-634. doi: 10.1080/14675986.2016.1259093.

Kyuchukov, H. (2014) Acquisition of Romani in a bilingual context. Psychology of Language and Communication, 18 (3), 211-225. doi: 10.2478/plc-2014-0015.

Kyuchukov, H. (2011) Romani language in the educational system of Bulgaria. International Journal of Romani Language and Culture, 1 (2), 173-187.

Kwadrans, L. (2010). Roma education - proposal on positive change. In: J. Balvin \& L. Kwadrans (Eds.). The Situation of the Roma minority in Czech, Hungary, Poland and Slovakia (pp. 333-342). Wroclaw: PROM.

Luciak, M. (2004). Minority status and schooling - John U. Ogbu's theory and the schooling of ethnic minorities in Europe. Intercultural Education, 15 (4), 359-368. doi: 10.1080/1467598042000313395.

Ogbu, J.U. (1978). Minority Education and Caste: The American System in Cross-Cultural Perspective. New York: Academic Press.

Ogbu, J.U. (1982). Cultural discontinuities and schooling. Anthropology and Education Quarterly, 13 (4), 290-307. doi: 10.1525/aeq.1982.13.4.05x1505w.

Ogbu, J.U. (1985). Cultural-ecological influences on minority education. Language Arts, 62(8), 860869.

Ogbu, J.U. (1990). Minority status and literacy in comparative perspective. Daedalus, 119(2), 141-168.

Ogbu, J.U. (2014). From cultural differences to differences in cultural frame of reference. In P.M. Greenfield \& R. Cocking (Eds.). Cross-cultural Roots of Minority Child Development (pp. 365391). New York: Psychology Press.

Samko, M. \& Kapalková, S. (2014). Analýza naratívnej schopnosti rómskeho diet’at’a v rómčine a slovenčine. Psychológia a patopsychológia diet'at'a, 48 (3-4), 372-384.

Vygotsky, L. (1978). Mind in Society: The Development of Higher Psychological Processes. Cambridge, MA: Harvard University Press.

(C) Kyuchukov, H., 2017

Article history:

Received 16 April 2017

Revised 5 June 2017

Accepted 14 June 2017

\section{For citation:}

Kyuchukov, H. Cultural-Ecological Theory and the Language Education of Roma Children. RUDN Journal of Psychology and Pedagogics, 14 (3), 290-300. DOI 10.22363/2313-1683-2017-14-3290-300

\section{Bio Note:}

Hristo Kyuchukov - Ph.D., Prof. Dr. Habil., Gest-Professor at Magdeburg-Stendal University of Applied Sciences (Magdeburg, Germany). E-mail: hkyuchukov@gmail.com 


\title{
КУЛЬТУРНО-ЭКОЛОГИЧЕСКАЯ ТЕОРИЯ И ЯЗЫКОВОЕ ОБРАЗОВАНИЕ ЦЫГАНСКИХ ДЕТЕЙ
}

\author{
Х. Кючуков \\ Магдебург-Стендаль Университет прикладных наук \\ Брэйчэйд штрассе, 2, Магдебург, Германия, 39114
}

\begin{abstract}
В статье представлены результаты языкового тестирования 70 цыганских детей из Болгарии - учеников 1 класса, обучающихся в крупнейшей цыганской школе в Софии, в округе Факултэта. Для тестирования использовался Словарный тест в картинках Пибоди (Peabody Picture Vocabulary Test), с помощью которого измерялось языковое понимание и продуцирование в начале и конце учебного года. Между первым и вторым тестированием изменились методы обучения - в классе появился цыганский ассистент учителя, задача которого была в использовании родного языка как средства коммуникации с учениками. Результаты повторного тестирования детей были намного лучше первого, что обсуждается в русле культурноантропологической теории американского антрополога Дж. Огбу, разработанной в 80 -е гг. $\mathrm{XX}$ в. Для статистической обработки был использован однофакторный дисперсионный анализ ( ANOVA). Согласно теории Огбу, академическая успешность школьников, относящихся к меньшинствам, значительно зависит от социальных установок общества и от уровня групповой поддержки. В статье также кратко рассматриваются причины того, почему попытки десегрегации цыганских детей и их интеграции в обычные школы в Болгарии во многом оказались неудачными.
\end{abstract}

Ключевые слова: культурно-экологическая теория, цыгане, родной язык, десегрегация, Болгария

(C) Кючуков X., 2017

История статьи:

Поступила в редакцию: 16 апреля 2017

Принята к печати: 14 июня 2017

\section{Для цитирования:}

Кючуков Х. Культурно-экологическая теория и языковое образование цыганских детей // Вестник Российского университета дружбы народов. Серия: Психология и педагогика. 2017. T. 14. № 3. C. 290-300. DOI 10.22363/2313-1683-2017-14-3-290-300

Сведения об авторе:

Кючуков Христо - Ph.D., профессор, приглашенный профессор Магдебург-Стендаль Университета прикладных наук (Магдебург, Германия). E-mail: hkyuchukov@gmail.com 